\title{
Effect of adding different levels of probiotic on in vitro gas production of noodle waste
}

\section{Besharati ${ }^{1,2}$, A Taghizadeh $^{1}$, A Ansari ${ }^{1}$}

${ }^{1}$ University of Tabriz, Tabriz, East Azarbyjan, Islamic Republic of Iran

${ }^{2}$ Payame Noor University of Benis, Shabestar, Islamic Republic of Iran

Email:ataghius@yahoo.com

Introduction Probiotics present an attractive alternative to the use of chemical and hormonal promoters in the livestock growth production industry. The preparations entail the safe production of micro-organisms and have been used for many years and thus are generally accepted by both the farmer and the final consumer. Saccharomyces cerevisiae supplementation in ruminant diets can increase DMI, production performance, cellulose degradation, and nutrient digestibility (Callaway and Martin, 1997). The gas measuring technique has been widely used for evaluation of the nutritive value of feeds. Gas measurement provides useful data on digestion kinetics of both soluble and insoluble fractions of feedstuffs (Getachew et al., 1998). In the gas method, kinetics of fermentation can be studied on a single sample and a relatively small amount of sample is required or a larger number of samples can be evaluated at one time. Besharati et al., (2009) showed that probiotics can increase in vitro gas production from feeds. The purpose of this study was to study the effect on the in vitro gas production of noodle waste when different amounts of Saccharomyces cerevisiae were added.

Material and methods Samples of rumen fluid were collected from two rumen cannulated sheep fed twice daily a diet containing forage $(400 \mathrm{~g} / \mathrm{kg})$ plus concentrate $(600 \mathrm{~g} / \mathrm{kg})$ after the morning feed, and were then strained through four layers of cheesecloth. Gas production in each serum bottles (vial) was measured using a water displacement apparatus (Fedorak and Hrudey, 1983). Approximately $300 \mathrm{mg}$ of dried and ground $(2 \mathrm{~mm})$ noodle waste sample was weighed and placed into serum bottles. There were three replicates per treatment. The treatment contained 0, 2.5, 5 and $7.5 \mathrm{~g}$ yeast Saccharomyces cerevisiae (Sc) per kg of noodle waste based on DM, respectively. Buffered rumen fluid with McDougal buffer (20ml, ratio of buffer to rumen fluid was 2:1) was pipetted into each serum bottle (McDougal, 1948). The gas production was recorded after 2, 4, 6, 8, 12, 16, 24, 36, and $48 \mathrm{~h}$ of incubation. Total gas values were corrected for the blank incubation, and reported gas values are expressed in $\mathrm{ml}$ per $1 \mathrm{~g}$ of DM. The data at the different times was analysed using completely randomized design by the GLM procedure of SAS Institute Inc (2002). The organic matter digestibility (OMD), ME and $\mathrm{NE}_{\mathrm{L}}$ contents of feed were estimated by the method of Menke and Steingass (1988). Samples of noodle waste were collected from food factories in the country of Tabriz.

Results Total gas production volume $(\mathrm{ml} / \mathrm{g} \mathrm{DM})$ in incubation times are shown in Table 1. At the early incubation times $(2,4,6$ and $8 \mathrm{~h}$ ), treatments 3 and 4 (treatment with Sc, 5 and $7.5 \mathrm{~g} / \mathrm{kg} \mathrm{DM}$, respectively) had the highest gas production volume among treatments, but after $8 \mathrm{~h}$ the gas production volume in treatment 4 (treatment with $\mathrm{Sc}, 7 \mathrm{~g} / \mathrm{kg} \mathrm{DM}$ ) was the highest ( $<<0.05$ ). Treatment 2 had the lowest gas production volume. Adding $5 \mathrm{~g} / \mathrm{kg}$ Saccharomyces cerevisiae or more to noodle waste increased the estimated amounts of $\mathrm{OMD}, \mathrm{ME}$ and $\mathrm{NE}_{\mathrm{L}}(\mathrm{p}<0.05)$.

Table 1 Total gas production volume ( $\mathrm{ml} / \mathrm{g} \mathrm{DM})$ in incubation times and estimated parameters*

\begin{tabular}{|c|c|c|c|c|c|c|c|c|c|c|c|c|}
\hline \multirow[b]{2}{*}{ Treatments } & \multicolumn{9}{|c|}{ Incubation times $(\mathrm{h})$} & \multicolumn{3}{|c|}{ Estimated parameters } \\
\hline & 2 & 4 & 6 & 8 & 12 & 16 & 24 & 36 & 48 & $\begin{array}{l}\text { OMD } \\
(\%)\end{array}$ & $\begin{array}{l}\mathrm{ME}(\mathrm{MJ} / \\
\mathrm{kg} \text { DM) }\end{array}$ & $\begin{array}{l}\mathrm{NE}_{\mathrm{L}}(\mathrm{MJ} / \\
\mathrm{Kg})\end{array}$ \\
\hline Control & $13.9^{\mathrm{b}}$ & $37.5^{\mathrm{b}}$ & $61.8^{\mathrm{b}}$ & $83.1^{\mathrm{b}}$ & $135.1^{\mathrm{c}}$ & $210.1^{\mathrm{bc}}$ & $306.2^{\mathrm{b}}$ & $355.6^{\mathrm{bc}}$ & $393.6^{\mathrm{b}}$ & $69.4^{\mathrm{b}}$ & $10.5^{\mathrm{b}}$ & $2.443^{\mathrm{b}}$ \\
\hline $\begin{array}{l}\mathrm{Sc} 2.5 \mathrm{~g} / \mathrm{kg} \\
\mathrm{DM}\end{array}$ & $10.6^{\mathrm{c}}$ & $25.9^{\mathrm{c}}$ & $45.4^{\mathrm{c}}$ & $66.2^{\mathrm{c}}$ & $121.7^{\mathrm{c}}$ & $191.7^{\mathrm{c}}$ & $280.9^{c}$ & $333.9^{c}$ & $372.2^{\mathrm{c}}$ & $64.9^{c}$ & $9.9^{\mathrm{c}}$ & $2.351^{\mathrm{c}}$ \\
\hline Sc $5 g / k g ~ D M$ & $26.6^{\mathrm{a}}$ & $53.7^{\mathrm{a}}$ & $77.7^{\mathrm{a}}$ & $99.9^{\mathrm{a}}$ & $153.8^{\mathrm{b}}$ & $231.6^{\mathrm{b}}$ & $316.4^{\mathrm{b}}$ & $369.8^{\mathrm{ab}}$ & $401.4^{\mathrm{b}}$ & $71.2^{\mathrm{b}}$ & $10.8^{\mathrm{b}}$ & $2.471^{\mathrm{b}}$ \\
\hline $\begin{array}{l}\mathrm{Sc} 7.5 \mathrm{~g} / \mathrm{kg} \\
\mathrm{DM}\end{array}$ & $31.6^{\mathrm{a}}$ & $61.1^{\mathrm{a}}$ & $85.1^{\mathrm{a}}$ & $111.9^{\mathrm{a}}$ & $175.4^{\mathrm{a}}$ & $258.1^{\mathrm{a}}$ & $344.2^{\mathrm{a}}$ & $392.5^{\mathrm{a}}$ & $421.3^{\mathrm{a}}$ & $76.1^{\mathrm{a}}$ & $11.6^{\mathrm{a}}$ & $2.572^{\mathrm{a}}$ \\
\hline SEM & 1.59 & 2.96 & 4.22 & 5.04 & 5.35 & 7.11 & 7.38 & 8.31 & 8.48 & 0.354 & 0.321 & 0.567 \\
\hline
\end{tabular}

* The means within a column without common letter differ $(\mathrm{p}<0.05)$.

Conclusions It was concluded that in vitro gas production parameters, $\mathrm{OMD}, \mathrm{ME}$ and $\mathrm{NE}_{\mathrm{L}}$ of noodle waste were improved with addition of $7.5 \mathrm{~g} / \mathrm{kg}$ DM yeast Saccharomyces cerevisiae, and yeast culture had potential of improving rumen fermentation characteristics.

Acknowledgement This study was funded by University of Tabriz, Tabriz, Iran.

\section{References}

Besharati, M ., A. Taghizadeh, A. Ansari. 2009. Proceedings of the BSAS. p187.

Getachew,G., Blummel, M., Makkar, H.P.S., and Becker, K. 1998. Animal Feed Science and Technology. 72:261-281.

Fedorak, P. M., and Hurdy, D. E., 1983. Environmental Technologist Letters. 4, 425-432.

Menke, K. H., and Steingass, H. 1988. Animal Research and Development. 28, 7-55.

SAS Institute INC.2002. Sas user's Guide: statistics. Statistical Analysis Systems Institute Inc. Cary NC. 